\title{
A SOCIOLINGUISTICS STUDY: STUDENTS' MOTIVATION UPON ELT IN THE COASTAL AREA OF BINTAN ISLAND
}

\author{
Nana Raihana Askurny ${ }^{1}$, Indah Pujiastuti² \\ ${ }^{1}$ English Education Study Program, Faculty of Teachers Traning and Education, \\ Universitas Maritim Raja Ali Haji \\ 2 Indonesian Language and Letters Department, Faculty of Teachers Training and Education \\ Universitas Maritim Raja Ali Haji
}

\section{Article Info}

Article history:

Submitted Nov 05, 2019

Revised Nov 26, 2019

Accepted Jan 03, 2020

Published April 30, 2020

\section{Keywords:}

Student

Motivation

Coastal Area

\begin{abstract}
Students who live in the coastal area in Bintan Island, Kepulauan Riau province, are expected to have greater access to the knowledge and information, regarding they stay in the open boundaries, Malacca straits. This social-region circumstance should enabled them to be familiar with English. However, students in this area do not conform to the expectation. This research utilizes qualitative design, where the determination of research question, subject, and design is based on the researcher. Researcher has taken more than a hundred of students, as the research subject who live and study in the coastal area, in Bintan Island. For data collection, questionnaire is arranged by adapting AMTB, Attitude Motivation Test Battery, by Gardner (2004). According to the data analysis, it describes that students have a sizeable motivation in learning English, whereas their capability is not equitable. This shape caused by two main factors, such as English teacher's role, real-contextual teaching method, and lack of opportunity
\end{abstract}

Corresponding Author:

Nana Raihana Askurny,

English Education Study Program, Faculty of Teachers Traning and Education

Universitas Maritim Raja Ali Haji

Jl. Polititeknik, Kampus Senggarang, Tanjungpinang

Email: nanaraihana@umrah.ac.id

\section{INTRODUCTION}

English language for students in the coastal area, in Kepulauan Riau or Kepri, is still assumed low performance. It gains the researcher to conduct a relating study to find out the reason behind this assumption. This year, researcher begins the study by investigating student's motivation upon English language teaching, in the coastal area, specifically in Bintan Island.

Bintan Island is the land which is surrounded by waters. It is located in the busy-hectictransportation path in the south-east Asia region, Malacca straits. It's normally expected that people who live in this island frequently meet foreigners, and assign for trading, working, and then even inter-human relation. Then, it is assumed and expected that people here are well-known to English language. nevertheless, students in the coast area, like in Bintan Island still achieves a low level of English performance.

This study attempts to find out how motivation of the students in this coastal area, Bintan island, in learning English in their classroom. As we know, motivation is one of supreme aspect that affect to the teaching learning achievement. This is the early step of macro investigation upon English language teaching research. Purposively, the later 
researches will be conducted to gain the complex and fully data and findings upon students' issues of coastal area.

\section{THEORY AND METHOD Motivation}

The researcher looks forward to know how orientation and perception upon English learning teaching of students in the coastal area. Since the English teachers, according to experience of the researcher who have supervised the teacher-candidates in the internship program, which claims that students' performance in English learning achievement is still unsatisfying.

Teaching learning consists of several elements which must be related and supported mutually. They are teacher, the person who deliver the knowledge, lead the students to the changing of behaviors, and foster the students to achieve the learning goal. Later, students, the subject who receive knowledge from the teacher, trigger themselves to go through new experiences, and the person who makes effort to achieve his life purpose through learning process. Then, teaching materials, materials which exerts the learner or students to gain his goal, and materials which is delivered properly and effectively to inspire learners to achieve his goal in the future through attending the school. Next is facility, facility is not obligatory since teachers, students, and materials are bound comprehensively, teaching learning still be able to be occurred. Nevertheless, school with sufficient facilities will perform better quality of teaching learning. Finally, external supported aspects, they are family and neighborhood of students.

This study takes one aspect of those, which is student, particularly motivation of students in the coastal area upon English language teaching. Coastal area, here, is Bintan Island. Bintan is one of the biggest islands in Kepulauan Riau province. It is surrounded by waters, and located in the seashore of the Malacca straits. The researcher investigated students' motivation within this area, when they served by English lesson. The position of this island, in where the students live, should be encouraged them to be more enthusiastic to learn English, therefore, the result of their learning should not be unsatisfied.

Motivation activates a person to do much more that he could achieved. Motivation is the feeling of enjoyable circumstance, a promising condition that he could gain, and comfortable moments, of somebody to conduct a work or duty. As stated by Harmer (2007) stated that motivation is some kind of internal drive which pushes someone to do things in order to achieve something. Someone who is motivated will be conditioned by a pressure situation, but still pursue his goal. Then Purwanto (2011) claimed that the word motivation is derived from motive that means anything that encourages person to act to do something. Later, Brown empowers this comprehensively understanding of motivation by stating that motivation is the extent to which you make choices about goals to pursue and the effort you will devote to that pursuit.

Motivation within English teaching learning context, for students, can be assumed by the desire to be succeed in the future, be the top students in the classroom, or even only for making a good score. These come from the inside of the student, which is next, noted as intrinsic motivation. Penny (1996), said that motivation can be alienated into two types, that are; intrinsic motivation (the urge to engage in the learning activity for its own sake) and extrinsic motivation (motivation that is derived from external incentives). Linear with the former experts, Biehler and Snowman (1993) illustrated that, motivation is typically defined as the forces that account for the arousal, selection, direction, and continuation of behavior. Both definitions imply that motivation comes from within a person; therefore, schools' responsibility is to create the conditions that will enhance students' motivation to pursue academic goals actively over a long period of time. 
Furthermore, Harmer stated that intrinsic motivation comes from within the individual. Then it illustrated by Gage and Berliner (1984) which gave a capture; another student may study hard for a test because he or she enjoys the content of the course. The next type is, extrinsic motivation. It comes from outside of the person or student. According Penny, extrinsic motivation derives from the influence of some kind of external incentive, as distinct from the wish to learn for its own sake or interest in tasks. A person when doing or fulfilling a duty, is because of outer sides' demands, such as social pressure, institution purpose, family demands, and even avoiding punishment. According Gage and Berliner stated this motivation appears or comes from teacher, parents, and environment.

1) Teacher, A major factor in continue of a student's motivation isthe teacher. Teacher has an important role in teaching learning activity. The teacher is not only a person who transfers the knowledge to the students, but also as a motivator who can motivate or support the students in learning activity.

2) Parents, A part from the culture of the world around students, their attitude to language learning will be greatly affected by the influence of people who are close to them. Harmer added the attitude of parents and older siblings will be crucial.18 Students who are encouraged by their parent will try new things and try to give high performance to get reward from their parent. As a result, they will get better achievement.

3) Environment, Outside any classroom there are attitudes to language learning and the English language in particular. The learning of English is important to be considered in the society. In a school situation, the language learning is part of the curriculum of thing status, the cultural images associated with English are positive.

\section{Coastal Area}

Kepulauan Riau province is well-known as an archipelago province. This province consists of collections of islands which are binding by waters. People here, economically, mostly live with counting on the sea sources. Thus, the coastal area, normally remains populous terrain. Dominantly, they are identified as Malay people, who speak Malay language fluently and live based on Malay culture and perception.

This research took Bintan Island as the location of the study. Like other islands, Bintan is surrounded by waters, and located in the middle of crowded path of water line transportation, Malacca straits. In Bintan Island there are two administrative districts that are Kabupaten Bintan and Tanjungpinang City. Kabupaten Bintan is the region which administered area in Bintan island excluded Tanjungpinang city. Meanwhile, Kota Tanjungpinang or Tanjungpinang city is determined as the capital city of Kepulauan Riau province.

There is no certain term or definition of coastal area, coast area, or coastal zone respectively. However, general commitment in the world claimed that coastal area or coastal zone is the switchover zone between land and ocean. Dahuri (2001:6) states coastal area is referring from the beach line, therefore coastal area consists of two kinds of boundaries that are, longshore boundary, which is defined as collateral boundaries with the beach/coast line, and cross-shore boundary, that boundary which is upright to the coast line.

Moreover, several experts from vary discipline attempted to define it. Like Isobe (1991), in his article, defines that Coastal zone can be narrowly thought of as the "dividing boundary" between sea and land-the coastline-or broadly thought of as the zone in which the three spheres of air (atmosphere), water (hydrosphere), and land (lithosphere) converge-the coastal zone. Coastal regions are intensely dynamic areas, and are of critical important to humans. Then, he also stated that Coastal zones contain unique, irreplaceable ecosystems. At the same time, coastal zones are subject to intense use by humans-for transportation activities, resources and energy, procurement, industrial uses, and 
recreation. And Nelson (2018) claimed that, a coastal zone is the interface between the land and water. These zones are important because a majority of the world's population inhabit such zones. Coastal zones are continually changing because of the dynamic interaction between the oceans and the land.

Provide method of the research in details that help reproducible research. It is written in past tense. It includes: participants, design, \& procedure. Avoid putting formula in this part. Tuliskan metode penelitian pada sub judul ini dengan jelas sehingga dapat dilakukan oleh peneliti lain. Dalam bentuk lampau. Bagian ini termasuk menjelaskan partisipan, desain penelitian, dan prosedur (Cambria 10 pt). Hindari memasukkan rumus pada bagian ini.

The researcher use descriptive qualitative method. The researcher observe, categorize, and decide the location and subject of the study. Bintan Island has two administrative region, Bintan and Tanjungpinang city, these two became location for data collection.

The researchers observes the phenomenon, constructs the problem, consults to the related theories, collects the data and analyzes it, discusses and concludes. Data or findings are the mattter of analysis. They have characteristics and pattern which be elligible to describe the real phenomenon of language use. According to Moleong (2014), a qualitative research is a investigation design to understand phenomena which experienced by the research subject, for instance attitude, perception, motivation, and acts.

\section{Research Subject}

Subject in this research are students of Junior and Senior High schools in Bintan and Tanjungpinang city. The determination of location based on the position of the schools which are surrounded or located at the coast line. In Tanjungpinang, took two schools, SMP Negeri 14 and 11 of Tanjungpinang. And, in Bintan took four schools which spread in the area of Toapaya, Kijang and Kawal. There are 213 students, have been taken as the subject.

\section{Instruments}

This research applied an instrument to investigate students' motivation on ELT in the coastal area, in Bintan Island. The researcher adapted questionnaire from Attitude/Motivation Test Battery: International AMTB, issued by Gardner (2004). There are 20 statements within the questionnaire which enable to gain students' motivation in coastal area, upon ELT.

\section{Questionnaire}

This research utilized questionnaire to gain the data. O'Leary (2014) states that Questionnaires have many uses, most notably to discover what the masses are thinking. These include: market research, political polling, customer service feedback, evaluations, opinion polls, and social science research. Bell and Waters (2014) started by reminding the researcher to obtain approval prior to administering their questionnaire, then to reflect on what our question is and whether this is the best method to obtain the intended information.

Moreover O'Leary, advises that operationalize concepts in the beginning and define the measurable variables. Variables in this study are motives or desires of students, including intrinsic andextrinsic motivation, which guided by Gardenr (2014), by AMTB.

The twenty statements within questionnaire were assumed to present motives, desires, and outer supports of the students in learning English subject. Here are the twenty statements which handed and filled by the students;

1. Saya merasa biasa saja ketika saya tidak pandai dalam pelajaran bahasa Inggris (I feel just fine when I am not good in the English class) 
2. Orang tua saya mendorong dan membantu saya untuk mempelajari bahasa inggris (My parents motivate and help me to study English)

3. Saya akan dengan mudah menguasai bahasa Inggris jika orang-orang di sekitar saya aktif menggunakan bahasa Inggris (I will be easy to master English if people around me speak English actively)

4. Bahasa Inggris, terutama grammarnya, sulit untuk dipahami (English, especially the grammar, is hard to be understood)

5. Pelajaran bahasa Inggris adalah pelajaran yang selalu saya tunggu karena guru yang mengajar adalah guru terfavorit bagi saya (English lesson is the subject that I always look forward to, because the teacher is my favorite teacher)

6. Pelajaran bahasa Inggris adalah pelajaran yang membuat perasaan tertekan (English is the lesson which makes me feel depressed)

7. Saya belum pernah melihat guru bahasa Inggris, menjelasakan materi grammar secara menarik (I have never met an English teacher explained grammar in the interesting way)

8. Saya lebih meyukai film berbahasa Indonesia dibandingkan dengan film berbahasa Inggris yang di-subtitle ke bahasa Indonesia (I would prefer Indonesia's language films to English language films with Indonesia language subtitled )

9. Keberhasilan siswa dalam belajar bahasa Inggris, tergantung pada cara guru menyajikannya (The student's succeed in learning English depends on how the teacher teaches)

10. Saya akan mendapat peluang kerja yang lebih hebat jika saya menguasai bahasa Inggris ( I will get the brighter job opportunity if I master English)

11. Saya kagum saat seseorang berbicara menggunakan bahasa Inggris (I am impressed to see somebody who speaks English)

12. Bahasa Inggris harusnya disajikan dengan cara yang lebih menarik agar tidak terasa rumit (English should be served in more attractive way in order to gain easiness)

13. Saya mendapat banyak pengetahuan kata-kata bahasa Inggris melalui internet (I got a lot of English words through internet)

14. Bahasa Inggris adalah mata pelajaran yang penting di sekolah (English is an important subject in school)

15. Saya ingin lebih menguasai bahasa Inggris untuk bisa lebih paham menggunakan internet dan gadget (I want to be more master in English in order to be more cognize in using internet and gadget)

16. Iklan produk-produk dagang di televisi dan internet, lebih menarik jika disajikan dalam bahasa Inggris (Advertisements of trading in the TV and Internet are more interesting when they are presented in English)

17. Saya tidak mempunyai alasan yang kuat untuk menyukai pelajaran bahasa Inggris (I don't have strong motive to love English lesson)

18. Saya selalu memotivasi diri sendiri walaupun mengalami kesulitan dalam belajar bahasa Inggris (I always motivate myself even I get through difficulties in learning English)

19. Menurut saya, Guru bahasa Inggris saya tidak pernah mengajar menggunakan materi yang menarik (According to me, my English teacher never taught interesting material of English)

20. Saya menonton film dan mendengarkan lagu berbahasa Inggris bukan untuk meningkatkan kemampuan berbahasa Inggris (I watch movie and listen to the song of English language not for advancing my English competence) 


\section{Categorization of Statement of Questionnaire}

The researcher categorized statements within questionnaire according to intrinsic and extrinsic motivation. Intrinsic motivation is the perception, desire, motive, or willingness which comes from the inside of the student. It is represented by statement number $1,4,6$, $8,10,11,13,14,15,17$, and 18 .

While, extrinsic motivation defined as factors which come across from the outside of the student that are teacher and environment. Teacher category has been covered by the statement number $7,5,9,12$, and 19 , and then, environment category presented by the statement number $2,11,13,15$, and 20 .

\section{Procedures}

The researcher use questionnaire which consists of 20 statements. These statements were responded by the students by selecting one option of available four options, they are strongly agree, agree, less agree, and disagree. The score, based on Likert Scale, of each option is, four, three, two, and one, for positive statements. Whereas, one, two, three, and four, for negative statements given by the researcher. Before conducting the questionnaire, the researcher explained briefly the purpose of this action, and how do the students able to respond the statements within the questionnaire, and what are positive or negative statement are aimed.

\section{FINDINGS AND DISCUSSION Data Analysis}

There are 203 students were participated to the questionnaire. All of the students have been categorized as part of people who live in the coastal area. They are mostly Malay, their parents live form fishing, and they speak Malay language. Therefore, in this occasion, use Bahasa Indonesia as the medium of questionnaire to avoid misunderstanding towards the students.

The data of this study were 203 sheets of questionnaire which taken in several schools in Tanjungpinang and Bintan region. By applying Likert Scale Scores, 4,3,2,1 upon the set of statements, researcher could investigate the students' motivation. As mentioned earlier, there are some statements constructed in negative that are statement number $1,4,6,7$, 17, 19, and 20. These statements are interpreted, based on Likert Scale Score, 1,2, 3, and 4 for the respond Strongly agree, less agree, agree, and disagree. After analysing data, thses negative statement responsed as follows;

Tabel 1

Negative Statement Interpretation

\begin{tabular}{|c|c|c|c|c|c|c|c|c|c|c|c|c|}
\hline \multirow[t]{2}{*}{ Respondent (203) } & \multicolumn{12}{|c|}{ Statements } \\
\hline & \multicolumn{4}{|c|}{1} & \multicolumn{4}{|c|}{4} & \multicolumn{4}{|c|}{6} \\
\hline (PN) & 1 & 2 & 3 & 4 & 1 & 2 & 3 & 4 & 1 & 2 & 3 & 4 \\
\hline Sum & 15 & 24 & 86 & 77 & 33 & 90 & 65 & 13 & 23 & 49 & 73 & 57 \\
\hline S X PN & 15 & 48 & 258 & 308 & 33 & 180 & 195 & 52 & 23 & 98 & 219 & 228 \\
\hline Total Score & \multicolumn{4}{|c|}{629} & \multicolumn{4}{|c|}{460} & \multicolumn{4}{|c|}{568} \\
\hline $\begin{array}{c}\text { Interpretation (index } \\
\% \text { ) }\end{array}$ & \multicolumn{4}{|c|}{77.46305419} & \multicolumn{4}{|c|}{56.65024631} & \multicolumn{4}{|c|}{69.95073892} \\
\hline Criteria & \multicolumn{4}{|c|}{ Diagree } & \multicolumn{4}{|c|}{ Less-Agree } & \multicolumn{4}{|c|}{ Less-Agree } \\
\hline
\end{tabular}


The table above attempts to explain how the researcher analyse the data. Here, the researcher only serve three examples of negative statements that have been responsed by the coastal area students, they are statement number 1, 4, and 6, indeed there are seven negative statements. The all of negative statements had been analysed by the researcher, but could not be presented on this article.

From the table showed that all of the respondent, 203 students, means that total number of students is 203. This table described that 203 students responsed to the statement 1, 4, and 6, with the score scale 1,2,3, and 4 . Before the researcher explained elaboratedly the data analysis based on the previous table, the list of symbols or terms of the calculation is needed to be concerned as follows,

Sum : the sum of respondents who selected a specific option, with score 1,2,3, or 4

$\boldsymbol{S}_{\boldsymbol{X}} \boldsymbol{P N} \quad$ : S multiplied by the specific score, whether 1, 2, 3, or 4

Total Score : The sum of $S \times P N$ of the four selected option within each statement

\section{Interpretation}

Index : Total score divided by Y, then multiplied by 100

$\boldsymbol{Y} \quad:$ X Mulitiplied with 4 , four means the number of available option, that is $\mathbf{8 1 2}$.

$X \quad$ : Number of the students, 203

Interval : 25, it comes from 100 divided by 4 . Since this questionnaire applies 4 options of response in each statement.

Next, the researcher gives the procedure of calculation in analyzing data. Let's take statement number 4 , negative statement. On the table above, the likert scale score, from the left to the right, are 1, 2, 3, and 4. From the data served that 203 students responded to this statement by picking up the one of four different options, then it is labeled as Sum as follows,

1. Option with the score 1 , are selected by 33 students,

2. Option with the score 2 , are selected by 90 students

3. Option with the score 3 , are selected by 65 students

4. Option with the score 4 , are selected by 13 students

Then $\boldsymbol{S} \boldsymbol{x} \boldsymbol{P N}$ score from each option above are;
1. $33 \times 1=33$
2. $90 \times 2=180$
3. $65 \times 3=195$
4. $13 \times 4=52$

After that, the Total Score can be calculated, by summing all the s x PN scores, which is defined as $33+180+195+52=460$.

Next step that needs to be calculated is to find interpretation index. Interpretation index defines how the data analysis served the condition that this study expected through research problem. Interpretation index means the score that arouse from percentage $100 \%$, ideally fact which is expected. Therefore this calculation involved the formula as; Interpretation index $(\mathbf{1 0 0} \%)=$ Total score

$$
\begin{aligned}
& \mathbf{Y} \mathbf{1 0 0} \\
& =460 / 812 \times 100 \\
& =77.46305419
\end{aligned}
$$

The researcher, then, able to describe that interpretation index with the value 77,460354 , indicates that students or research subject disagree with this negative statement. Therefore, it is interpreted that students' motivation is such good. This 
calculation procedure is applied on to each statement within the questionnaire, seven negative statements and thirteen positive statements.

\section{Result}

After applying calculation procedure to each data of statements within the questionnaire, accordingly, this study comes to the result. As presented by table below, it is accepted that research subject, that are the students, have good motivation in English language teaching, in the simple way, can be observed that they are motivated to learn English.

From the following table, it can be recognized that students' motivation emerged from the inside of the student and outer of the students, such are parents, environtment, and teacher. Intrinsic motivation covered by ten statements of questionnaire, which are 1 , $4,6,8,10,11,13,14,15,17$, and 18.

Parents' contribution is categorized as environment category of aspects, they are the statement number $2,11,13,15$, and 20 . In composing the questionnaire, the researcher put equal portions of teachers' and environement's factor of category, they are 7, 5, 9, 12, and 19.

Tabel 2

Recapitulation of Data Analysis

\begin{tabular}{|ccc|}
\hline Statement Number & $\begin{array}{c}\text { Interpretaion } \\
\text { Index }\end{array}$ & Criteria \\
\hline $\mathbf{1}$ & 77.46305419 & Disagree \\
\hline $\mathbf{2}$ & 74.75369458 & Agree \\
\hline $\mathbf{3}$ & 84.60591133 & Strongly Agree \\
\hline $\mathbf{4}$ & 56.65024631 & Less agree \\
\hline $\mathbf{5}$ & 61.69950739 & Agree \\
\hline $\mathbf{6}$ & 69.95073892 & Less Agree \\
\hline $\mathbf{7}$ & 61.8226601 & Less Agree \\
\hline $\mathbf{8}$ & 67.36453202 & Agree \\
\hline $\mathbf{9}$ & 79.67980296 & Strongly Agree \\
\hline $\mathbf{1 0}$ & 87.19211823 & Strongly Agree \\
\hline $\mathbf{1 1}$ & 83.62068966 & Strongly Agree \\
\hline $\mathbf{1 2}$ & 83.37438424 & Strongly Agree \\
\hline $\mathbf{1 3}$ & 74.87684729 & Agree \\
\hline $\mathbf{1 4}$ & 75.24630542 & Strongly Agree \\
\hline $\mathbf{1 5}$ & 79.92610837 & Strongly Agree \\
\hline $\mathbf{1 6}$ & 54.92610837 & Agree \\
\hline $\mathbf{1 7}$ & 62.80788177 & Less Agree \\
\hline $\mathbf{1 8}$ & 78.69458128 & Sangat Setuju \\
\hline 19 & 68.96551724 & Kurang Setuju \\
\hline $\mathbf{2 0}$ & 70.93596059 & Kurang Setuju \\
\hline & & \\
\hline & & \\
\hline
\end{tabular}

This table presents the result of intrinsic and extrinsic motivaton that has been gained in this research. The researcher structures the result in to two kinds, that are intrinsic motivation, which is inside the students, and extrinsic motivation, emerged from outer of the students.

\section{Result of Intrinsic motivation}

As narrated earlier that for getting data and result of intrinsic motivation, the researcher structured ten statements within the questionnaire, that are $1,4,6,8,10,11,13,14,15$, 17 , and 18.

The researcher narrates the result of these ten statements, by starting with statements which are applied in negative form, that are statement number 1, 4, 6, and 17. 
Then, from the table above, it can bee seen that these four statements interpreted as follows;

a) Statement number 1 , has interpration index as 77.46305419 , with criteria category disagree.

b) Statemnet number 4, has interpretation index as 56.65024631, with criteria category less agree.

c) Statement number 6, has interpretation index 69.95073892, with criteria category less agree, and

d) Stamen number 17, has interpretation index 62.80788177, with criteria category less agree.

Then, the researcher attempt to briefly illustratate the rest of statements, which are positive statement, upon intrinsic motivation, such are $8,10,11,13,14,15$, and 18 . The result illustration can be read as follows;

a) Statement number 8 , has interpretation index 67.36453202 , with the criteria category as agree

b) Statement number 10, has interpretation index 87.19211823, with the criteria category as strongly agree

c) Statement number 11, has interpretation index 83.62068966, with the criteria category as strongly agree

d) Statement number 13 , has interpretation index 74.87684729 , with the criteria category as agree

e) Statement number 14, has interpretation index 75.2463054274 , with the criteria category as strongly agree

f) Statement number 15, has interpretation index 79.92610837, with the criteria category as Strongly agree

g) Statement number 18, has interpretation index 78.69458128, with the criteria category as strongly agree

\section{Result of Extrinsic Motivation}

In this study, the researcher categorizes extrinsic motivation into two kinds, they are teachers and environment. In environment, the researcher include parents' role.

Teachers' Contribution Result

Teachers' contribution or role is set in the several number of statements, which are 7, 5, 9, 12, and 19. Negative statement are noted on statement number 7 and 19, whereas, 5, 9, and 12 , are noted on the positive statements.

Result of negative statements upon teachers' role illustrated as follows

a) Statement number 7, has interpretation index 61.8226601, with the criteria as less agree

b) Statement number 19 , has interpretation index 68.96551724 , with the criteria as less agree

Next, the description of positive statements upon teachers' contribution is illustrated below,

a) Statement number 5, has interpretation index 61.69950739, with the criteria as less agree

b) Statement number 9, has interpretation index 79.6798029661 .8226601 , with the criteria as agree

c) Statement number 12 , has interpretation index 83.37438424 , with the criteria as strongly agree

\section{Environment Contribution}

In this study, the researcher categorizes parents' role, commercial advertisement, internet use, and film in the environment contribution, which defined as extrinsic 
motivation. The result on this motivation is represented by seeing the data analysis of statements within the questionnaire, whether positive or negative way of statements. There are number $2,11,13,15$, in positive form of statements, and statement number 20 is negative form of statement.

The researcher narrates the result of these ten statements, by starting with statements which are applied in negative form, that are statement number 2,11, 13, and 15. Then, from the table above, it can bee seen that these four statements interpreted as follows;

a) Statement number 2, has interpretation index 74.75369458 , with the criteria as less agree

b) Statement number 11, has interpretation index 83.62068966, with the criteria as strongly gree

c) Statement number 13 , has interpretation index 74.87684729 , with the criteria as agree

d) Statement number 15, has interpretation index 79.92610837, with the criteria as strongly agree

Whereas, the result of statement number 20, whish is negative, illustrates as follows;

a) Statement number 20, has interpretation index 70.93596059 , with the criteria as less agree

\section{Recapitulation of Result}

In the positive statements, criteria from students' responses categorized strongly agree and agree criteria is assumed to be good motives. Therefore, positive statements with strongly agree and and agree affirmed good motivation of the students. On the oher hand, negative statements which have disagree and less agree criteria, based on the data analysis previously, indicates worthy motives or affirming good motivation of the students.

This following table shows the recapitulation of intrinsic and extrinsic motivation, which arouse from the table 2, table of Recapitulation of Data Analysis,

Table 3

Recapitulation of Result

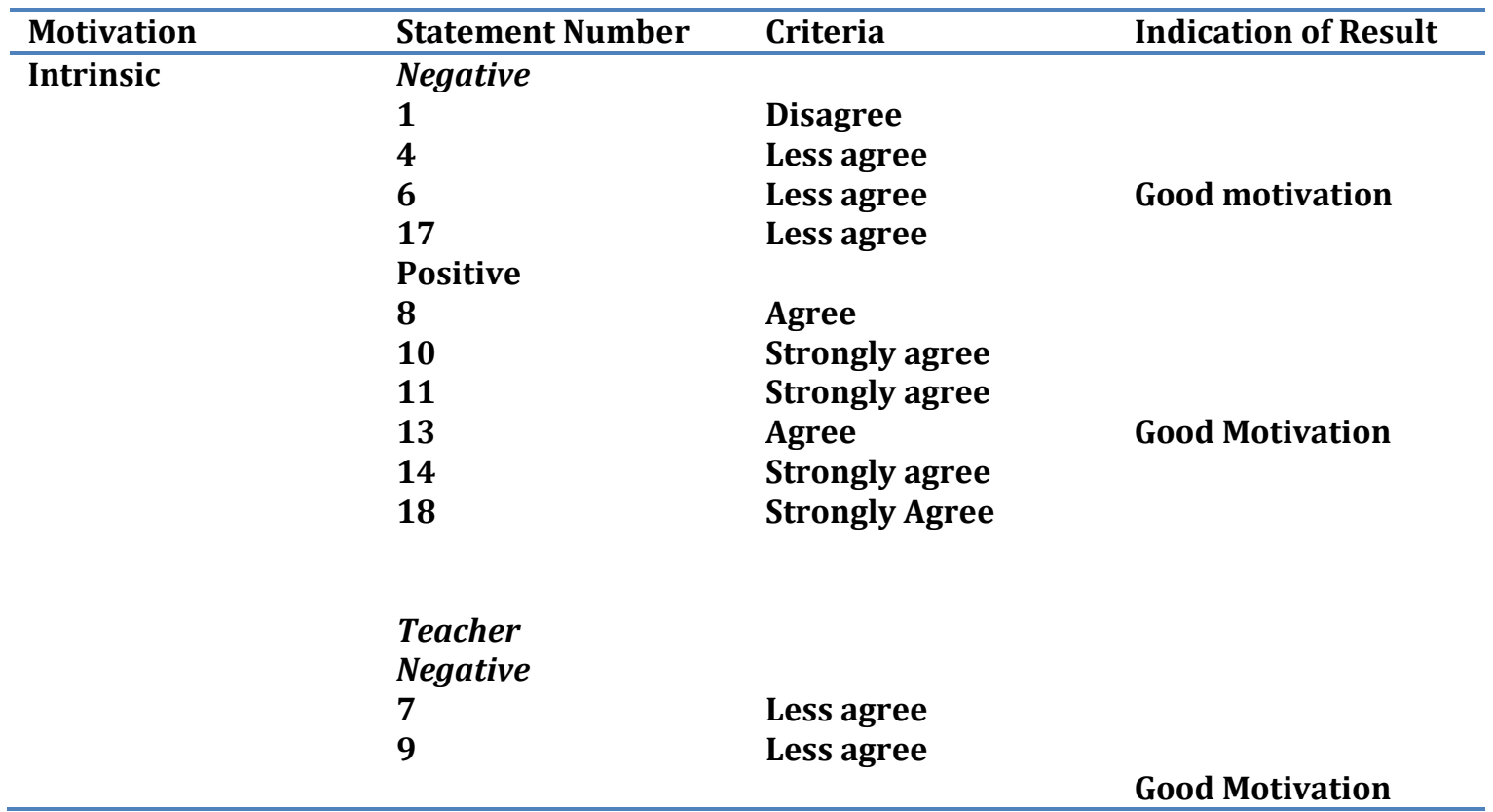




\begin{tabular}{llll}
\hline Extrinsic & Positive & Less agree & \\
$\mathbf{5}$ & $\begin{array}{l}\text { Agree } \\
\text { Agree }\end{array}$ & Bad Motivation \\
19 & & Good Motivation \\
Environment & & \\
Negative & Less agree & Good Motivation \\
20 & & \\
Positive & $\begin{array}{l}\text { Agree } \\
\text { Strongly agree } \\
\text { Agree } \\
\text { Strongly agree }\end{array}$ & Good Motivation \\
& & \\
11 & & \\
13 & & & \\
& & & \\
\hline
\end{tabular}

This table shows that positive statement that gain strongly agree and agree criteria of responses indicate that tha statements able to represent valuable or good result. But, in the contrary, when these positive statements gaining less agree and disagree criteria, it indicate bad motives, or not implying the good motivation. While, negative statements which gain less agree and disagree responses, it tells that the responses disagree to the given statements, it means, the indication of good motives or valuable motivation comes over. Moreover, whereas, negative statements implicates the contrary interpretation.

However, from the table above, Table 3, there is an distinctive fact, that is statement number 5, positive statement, gains less agree criteria of response, ideally, it was expected to be agree or strongly agree to get good motives purposely.

Statement number 5 is given as; English lesson is the subject that I always look forward to, since the teacher is my favorite teacher, from the data analysis, 203 students in the coastal area, in Bintan island responsed this statement with less agree. The researcher comes to the final assumption that students are motivated to study English, do not consider whether the teacher is favorite for them or not.

\section{CONCLUSION}

This study finally comes to the closing part. This study is the earlier step of sustainable set of studies. At the beginning study of that, is to figure out how the motivation of the coastal area students in Bintan Island. This study applied a qualitative descriptive, which equipped with a simple calculation upon the data collection that arouse from the questionnaire.

From the data analysis, it seems that students' motivation to study English is good. Motivation, here, involved intrinsic and estrinsic motivation. There are ten statements which drilled students' motives and desires toward English classroom lesson, and the result of this, presents the respectable or good motivation. In the simple way, the researcher claims that students, in this area, are passionated to study English.

Extrinsic motivation is able to be visible from the data analysis. The researcher constructed ten statements with involving parents' role, teacher's contribution, internet use, surrondings, and future dream as motives for students to react or response the given questionnaire. It presented that the students, commonly, are inspired with English teaching learning, which meant they showed good motivation. There was only one statement that didn't show the purposive expectation that is statement number 5 . In this statement, the researcher gave illustration about English teacher, which is a favorite teacher, as the factor of good motivation. Based on the data analysis, this statement 
responsed with less agree criteria, it is positively assumed that students do not consider like or dislike to the personal figure of the English teacher.

This study still needs further exploration and investigation. Regarding that students' achievement on English lesson is still unsatisfying. The two contadictary empirical facts, good motivation of the students which is good, and the low performance of students upon English are strongly recommended to be much deeper investigation.

\section{REFERENCES}

Bell, J., Waters, S., \& Ebooks Corporation. (2014). Doing your research project: A guide for first-time researchers (Sixth ed.). Maidenhead, Berkshire: Open University Press

Biehler, R, F., and Snowman, J. (1993). Psychology applied to teaching (7th Ed.), Boston: Houghton Mifflin.

Dahuri, R et al. (2001). Pengelolaan sumber daya wilayah peisisir dan lautan secara terpadu. Jakarta: PT.Pradnya Paramita

Gage, NL \& David C. Berliner. (1984) Educational psychology, (Boston: Houghton Mifflin Company,1984), P. 374

Gardner (2004), Attitude/motivation test battery: International AMTB research project, The University of Western Ontario, Canada

Harmer, Jeremy. (2007). The practice of English language teaching. Fourth edition, Malaysia : Longman Pearson Education Limited,P.51

Isobe, Masahiko. (1998). Toward integrated coastal zone management in Japan, presented at the ESENA Workshop: Energy-Related Marine Issues in the Sea of Japan Tokyo, Japan 11-12 July 1998

Moleong, Lexi, J. (2014), Penelitian kualitatif,, Bandung: PT.Remaja Rosdakarya.

Nelson, R, et.al. (2018), How to make Integrated Coastal Erosion Management a reality, Ocean and Coastal Management Journal, Volume 156, 15 April 2018, Pages 290299, https://www.sciencedirect.com/science/article/abs/pii/S0964569118300346

O'Leary, Z. (2014). The essential guide to doing your research project (2nd ed.). London: SAGE.

Penny, Ur. (1996). A course in language teaching. New York: Cambridge University Press.P.2769 John W. Santrock, Educational Psychology, (New York: Mc-Graw Hill, 2004),P. 418

Purwanto. (2011). Evaluasi hasil belajar. Yogyakarta: Pustaka Pelajar. Rubiyanto, Rubino. 